\title{
Andersen-Tawil syndrome - a case report
}

\section{Zespół Andersen-Tawil - opis przypadku}

\author{
Katarzyna Wójcik-Borowska' (D), Magdalena Chrościńska-Krawczyk² (D), Ewa Zienkiewicz (D), \\ Magdalena Małka ${ }^{4}$ (D), Maria Klatka ${ }^{5}$ (iD)
}

1 Klinika Hematologii, Onkologii i Transplantologii Dziecięcej, Uniwersytecki Szpital Dziecięcy w Lublinie, ul. prof. Antoniego Gębali 6, 20-093 Lublin

2,3 Poradnia Neurologiczna Polikliniki, Uniwersytecki Szpital Dziecięcy w Lublinie, ul. prof. Antoniego Gębali 6, 20-093 Lublin

4,5 Poradnia Endokrynologiczna, Uniwersytecki Szpital Dziecięcy w Lublinie, ul. prof. Antoniego Gębali 6, 20-093 Lublin

DOI:10.20966/chn.2018.54.423

\section{STRESZCZENIE}

Zespół Andersen-Tawil (Andersen-Tawil syndrome - ATS, long OT syndrome type 7, LOTS Type 7) jest rzadko występującą kanałopatią potasową, spowodowaną głównie mutacją genu KCNJ2. Część przypadków spowodowana jest mutacją genu KCNJ5. Mutacja dziedziczona autosomalnie dominująco jest wykrywana u około $60 \%$ pacjentów z rozpoznanym zespołem. Około $30 \%$ mutacji może być spowodowanych de novo. Obraz kliniczny obejmuje triadę objawów: okresowe, napadowe osłabienie siły mięśniowej występujące po dłuższym spoczynku lub w trakcie spoczynku po intensywnym wysitku fizycznym, wydłużenie odstępu OT wraz z zaburzeniami rytmu serca i cechy dysmorficzne (m.in. niski wzrost, hypoteloryzm, hipoplazja żuchwy, krótkie palce rąk i stóp).

Duża zmienność fenotypowa oraz często subtelne objawy kliniczne powodują trudności diagnostyczne. Jednak wczesne rozpoznanie jest kluczowe ze względu na możliwości zapobiegania i leczenia objawów neurologicznych oraz zaburzeń rytmu serca, które mogą być przyczyną nagłego zgonu.

Celem pracy jest przedstawienie przypadku 15 letniego pacjenta z zespołem Andersen-Tawil.

Słowa kluczowe: Zespół Andersen-Tawil, arytmia serca, cechy dymorficzne, KCNJ2, napadowy paraliż mięśniowy
ABSTRACT

Andersen-Tawil syndrome is a rare potassium ion channelopathy. Mutations in KCNJ2 are the primary cause. The second causative gene is KCNJ5. Mutations inherited as an autosomal dominant characteristic, are usually found in $60 \%$ of patients with the diagnosed syndrome. De novo mutations occur in $30 \%$ of cases. The clinical presentation of the syndrome includes: periodic, paroxysmal muscular weakness occurring after prolonged rest or during rest after prolonged physical exertion, prolonged OT interval, cardiac arrhythmias and dysmorphic features (short stature, hypertelorism, hypoplastic mandible, short fingers and toes).

Phenotypic heterogeneity and subtle physical symptoms cause diagnostic difficulties. However, early diagnosis is crucial because of the possibility of prevention and treatment of neurological symptoms and cardiac arrhythmias, which can be the cause of sudden death.

The aim of this paper is to present the case report of a 15-year-old patient with Andersen-Tawil syndrome.

Keywords: Andersen-Tawil syndrome, cardiac arrhythmias, dysmorphic features, KCNJ2, periodic paralysis,

\section{INTRODUCTION}

The first case of the familial occurrence of muscular paralysis and ventricular ectopy was described in 1963 by Klein [1]. The next case, of an 8-year-old boy with muscular weakness and ventricular arrhythmia, was described by Dr. Ellen Damgaard Andersen in 1971 [2]; in addition, the patient demonstrated short stature, low-set ears, hypoplastic mandible and aplasia of some teeth [3]. In subsequent years individual papers describing similar cases were published. In 1994, after describing 4 new patients and analyzing 10 previously described cases, Dr.Tawil discovered that this disease is inherited mainly in an autosomal dominant manner[4]. Finally, in 2003, the name "Andersen syndrome" was changed to "Andersen-Tawil syndrome" in recognition of the studies conducted by Dr. Tawil and his contribution to broadening knowledge about the disease[3].
This syndrome is inherited in an autosomal dominant manner, but its phenotype may vary, even in members of the same family. Some cases of reduced penetrance occur. Approximately $2 / 3$ of cases of the disease are caused by mutation of the KCNJ2 gene, responsible for the production of the protein used in the Kir2.1 channel for potassium current $\mathrm{I}_{\mathrm{K} 1}$ [5]. The Kir channel is the so-called inward rectifier channel stimulated by an increase of the extracellular concentration of $\mathrm{K}+$ ions and membrane hyperpolarization. These channels are susceptible to slight elevations of extracellular concentration of potassium ions, and their activity constitutes the resultant function combining membrane potential and potassium ion balance potential $[5,6]$.

Gene mutation causes defects in the structure and function of the ion potassium channel, which leads to distur- 
bances in the repolarization process in cells of the skeletal muscles and the myocardium.

According to recent reports, ATS may also be caused by mutation of the KCNJ5 gene that encodes the G protein, which activates the potassium channel Kir3.4. Mutation was detected in a patient with diagnosed Andersen-Tawil syndrome who did not reveal mutation of KCNJ2. The patient demonstrated paroxysmal paralysis and cardiac arrhythmia, but did not show any dysmorphic features $[7,8]$.

\section{CASE REPORT}

Care providers reported to the Neurology Outpatient Clinic of the Paediatric Clinical Hospital in Lublin with an 8-month-old child due to delayed psychomotor development. Perinatal history: boy of $2^{\text {nd }}$ pregnancy, $1^{\text {st }}$ delivery, born by Cesarean section in week 38 of pregnancy, Apgar score 5,6,8. In the postpartum period cardiac arrhythmias in the form of sinus arrest were found, and the ECG showed a tendency to prolonged QT. The patient's mother, her sisters and her father demonstrated long QT syndrome, cardiac arrhythmia in the form of premature ventricular contractions, as well as paroxysmal syncopes, short stature and signs of facial dysmorphia. The patient's mother died because of cardiac arrythmia at the age of 28 . She did not undergo diagnostics for Andersen-Tawil syndrome.

Physical examination revealed the following dysmorphic features in the patient: hypertelorism, short palpebral fissures, hypoplasia of mandible, thin upper lip, birdlike appearance of the face, low-set ears, fifth-digits clinodactyly, small hands and feet, short stature $(<3$ th centile for age, body weight -10 th centile for age). Due to the family history and clinical picture, the boy was examined by a cardiologist and cardiac arrhythmia was detected. A molecular genetics evaluation was performed which revealed mutation A304D in one allele in the KCNJ2 gene. Mutation for KCNJ2 gene not yet registered in the mutation database HGMD (human gene mutation data). PolyPhen and Sift technologies that predict whether the amino acid substitution influences the function of the protein classified this mutation as pathogenic. Andersen-Tawil syndrome was diagnosed. The boy remains under the care of the Neurology Outpatient Clinic.

During regular visits, neurological examination revealed no symptoms of focal damage to the central nervous system and no signs of neurological syndrome. However, signs of facial dysmorphia (birdlike nose, hypoplastic mandible) were described. Periodically, the patient demonstrated signs of axial and peripheral muscle weakness. The patient reported generalized weakness in the upper and lower limbs after exercise lasting several hours and periodic chest pain. These symptoms were unrelated. There were no symptoms in front of periodic paralysis. At the age of 10 a long exertional McManis test was performed with both increment and decrement being in the superior limit range.

The boy was hospitalized several times at the Department of Cardiology due to cardiac arrhytmia. The ECG revealed asymmetric, prolonged T-waves and enlarged $\mathrm{U}$ waves in recordial leads, especially in V2-3 leads. A 24hour Holter monitor showed sinus rhythm, the QTc inter- val max.500 milliseconds. Moreover, monorphic, single, venricular premature beats were noticed in ECG but with no complex cardiac arrhythmia and bidirectional ventricular tachycardia. In echocardiography non-disfunctional bicuspic aortic valve was found.

Due to short stature the patient was also tested for growth hormone deficiency, which was excluded. In the further diagnostic process hypothyroidism was identified.

At the age of 12 years behavioural abnormalities were observed in the form of periodical anxiety. A CT-scan of the CNS, and EEG evaluation conducted at that time were normal. During subsequent visits the care providers did not report any occurrence of similar episodes.

At present, the patient remains under specialist care of a neurologist, a psychologist, a cardiologist, an orthopedic surgeon and a physiotherapist. For pharmacological treatment metoprolol in a starting dose of $0,75 \mathrm{mg} / \mathrm{kg} /$ day was applied. After that that the dose of metoprolol has been increased up to $1,25 \mathrm{mg} / \mathrm{kg} /$ day. Furthermore the patient receives Euthyrox, potassium and magnesium supplementation.

\section{DISCUSSION}

Clinical symptoms of Andersen-Tawil syndrome are highly diverse, which causes diagnostic difficulties. A triad of symptoms, which comprises dysmorphic features, paroxysmal muscular paralysis and cardiac arrhythmia, constitutes the basis, but these symptoms may demonstrate various intensity, and they may occur in various correlations. Episodic muscular weakness or periodic paralysis is usually the main clinical feature that leads the patient to seek medical help. Periodic paralysis is a key phenomenon for early diagnosis of the syndrome. The onset of episodes usually precedents the cardiac abnormalities [4].

In some patients the only abnormality may be the occurrence of a prolonged QT interval, which may be incidentally diagnosed. Furthermore, in some patients the QT interval may be normal [9]. Dysmorphic features are usually subtle, and they may remain unnoticed. In addition, patients demonstrate mild difficulties in learning, and neurocognitive phenotype deficits in executive function and abstract reasoning [10].

According to the most recent guidelines [10], Andersen-Tawil syndrome should be suspected if:

A) Two out of three characteristic features of the syndrome are present:

1) paroxysmal muscular paralysis,

2) cardiological abnormalities such as: symptomatic cardiac arrhythmia(variety of arrhytmias can be detected in the patients, from isolated premature ventricular beats to complex ventricular ectopy and polymorphic ventricular tachycardias such as bidirectional ventricular tachycardia), ECG abnormalities such as: prominent U-wave, ventricular ectopy, prolonged QT interval. Structural anomalies of the cardiovascular system have also been reported. They include bicuspid aortic valve insufficiency with or without aortic coarctation, and stenosis of the pulmonary artery valve. 
3) characteristic facial appearance, teeth anomalies (multiple missing teeth, dental crowding, primary permanent dentition), small hands and feet, and at least two out of the following features:

- low-set ears

- hypertelorism

- hypoplastic mandible

- clinodactyly of the $5^{\text {th }}$ finger

- syndactyly between the $2^{\text {nd }}$ and $3^{\text {rd }}$ fingers

Other abnormalities have also been reported: cryptorchidism, vaginal atresia, hyperthyroidism, unilateral kidney dysplasia.

B) If the patient demonstrates one of the three aforemen-

tioned features, and in addition, in one family member

two of the aforementioned features are present (11).

Within differential diagnostics, the following should be ruled out: primary and secondary periodic paralysis, thyrotoxic periodic paralysis, and conditions related to prolonged QT interval $[4,10]$. The patient has to remain under the strict care of many specialists, mainly a paediatric neurologist and a paediatric cardiologist. In reference to each patient, ECG evaluation, Holter ECG monitoring, as well as determination of the level of the thyroid hormones and potassium during paroxysmal muscular weakness and within the period without attack should be performed. A paediatric endocrinologist should perform diagnostics for somatotropin hypopituitarism. It is necessary to provide orthopaedic and rehabilitation care in order to monitor potential faulty posture. It is also important to provide psychological and psychiatric care, because patients with Andersen-Tawil syndrome demonstrate behavioural disturbances and cognitive dysfunctions.

Carbonic anhydrase inhibitors (Acetazolamid), which shorten the duration of the attack of muscular paralysis and reduces the frequency of their occurrence, are successfully used in these patients [9].

During an attack of muscular paralysis associated with reduced potassium concentration in blood serum, it is indicated to administer oral potassium preparations 20-30 $\mathrm{mEq} / \mathrm{L}$ every 15-30 minutes (the dose of $200 \mathrm{mEq}$ should not be exceeded during 12 hours) until its concentration is normal. If these attacks are caused by low potassium concentration, its chronic substitution in the form of prolonged release preparations should be considered. It is assumed that mild physical effort may reduce the incidence and intensity of attacks [10]. It is crucial to identify factors triggering symptoms. The literature describes cases of using flecainide in patients with frequent, ventricular arrhythmia and impaired left ventricle function. In addition, beta-blockers and calcium channel blockers are used [11]. In some patients it is necessary to insert an implantable cardioverter defibrillator. Due to the risk of occurrence of lifethreatening cardiac arrhythmia it is important to inform patients with a prolonged QT interval what drugs should not used (salbutamol, thiazides and other non- potassiumsparing diuretics) [10].

Genetic counselling should include the patient's whole family with diagnosed defects of the KCNJ2 gene.

\section{SUMMARY}

Andersen-Tawil syndrome is a rare disease which is difficult to diagnose due to its varying intensity and compilations of symptoms. This should be kept in mind and suspected in persons who reveal signs of facial dysmorphia and cardiac arrhythmia. It is necessary to perform ECG evaluation in these patients, which may reveal pathology in the form of long QT syndrome or other abnormalities such as, e.g., premature ventricular contractions, or polymorphic ventricular tachycardia [7]. Early diagnosis is very important due to the possibility of implementing suitable management which may prevent sudden death caused by cardiac arrhythmia.

\section{REFERENCES}

[1] Klein R., Ganelin R., Marks JF., et al.: Periodic paralysis with cardiac arrhythmia. J Pediatr. 1963; 62: 371-385.

[2] Andersen ED., Krasilnikoff PA., Overvad H.: :Intermittent muscular weakness, extrasystoles, and multiple developmental anomalies. A new syndrome? Acta Paediatr Scand 1971; 60: 559-564.

[3] Tawil R., Ptacek L.J., Paclakis S.G. et al.: Andersen`s syndrome: potassium-sensitive periodic paralysis, ventricular ectopy, and dysmorphic features. Ann Neurol.1994;35:326-330

[4] Kotulska A., Kucharz E.J.: Andersen-Tawil syndrome - a review of the literature and a case report, Reumatologia 2008; 46,3: 171-174.

[5] Chrissobolis S., Sobey C.G.: Inwardly rectifying potassium channels in the regulation of vascular tone. Curr. Drug Targets, 2003; 4: 281-289.

[6] Sobey C.G.: Potassium channel function in vascular disease. Arterioscler. Thromb. Vasc. Biol., 2001; 21: 28-38.

[7] Kokunai Y., Nakata T., Furuta M., et al.: A Kir3.4 mutation causes Andersen-Tawil syndrome by an inhibitory effect on Kir2.1. Neurology 2015; 82: 1058-1064.

[8] Almuqbil M., Srour M.: Andersen-Tawil syndrome. Child Neurology 2015; 84(11), 78-80.

[9] de Campos C.F., de Carvalho M.: Neurophysiologic characterization of periodic paralysis episode in a patient with Andersen -Tawil syndrome, Clinical Neurophysiology (2017)

[10] Aravindhan Veerapandiyan, MBBS, Jeffrey M Statland, MD, Rabi Tawil, MD: Andersen-Tawil Syndrome Synonym: Long OT Syndrome Type 7 (LOTS Type 7), Gene Reviews, November 22, 2004

[11] Jeffrey M., Statland, MD, Bertrand Fontaine, MD et al.: Review of the Diagnosis and Treatment of Periodic Paralysis. Muscle Nerve 2018 Apr; 57(4): 522-530. 
